\title{
Open Innovation of James Watt and Steve Jobs: Insights for Sustainability of Economic Growth
}

\author{
JinHyo Joseph Yun ${ }^{1, *}$, Kwangho Jung ${ }^{2}$ and Tan Yigitcanlar ${ }^{3}$ \\ 1 Daegu Gyeongbuk Institute of Science and Technology (DGIST), 333, Techno Jungang-daero, \\ Hyeonpung-myeon, Dalseon-gun, Daegu 42988, Korea \\ 2 Korea Institute of Public Affairs, Graduate School of Public Administration, Seoul National University, \\ 1 Gwanak-ro, Gwanak-gu, Seoul 086626, Korea; kwjung77@snu.ac.kr \\ 3 School of Civil Engineering and Built Environment, Queensland University of Technology (QUT), \\ 2 George Street, Brisbane, QLD 4001, Australia; tan.yigitcanlar@qut.edu.au \\ * Correspondence: jhyun@dgist.ac.kr
}

Received: 11 May 2018; Accepted: 12 May 2018; Published: 14 May 2018

\begin{abstract}
This paper analyzes open innovation approach similarities and differences of James Watt and Steve Jobs-symbolic entrepreneurs of the First and Fourth Industrial Revolutions, respectively. The methodologic approach includes a review of the literature. Firstly, the key characteristics of the First and Fourth Industrial Revolutions are determined by comprehensively reviewing the literature-particularly books on both legendary innovation entrepreneurs. Secondly, the related preceding research that describes open innovation characteristics that James Watt and Steve Jobs possessed are critically analyzed. Thirdly, open innovation strategies promoted by the two innovation entrepreneurs are scrutinized by analyzing the related literature. The findings reveal the common and differing points of the two entrepreneurs' open innovation strategies and approaches. This paper serves as an editorial piece and introduces the special issue entitled 'Sustainability of Economic Growth: Combining Technology, Market, and Society', where the special issue contains 19 papers directly related to the open innovation strategy of Steve Jobs and James Watt.
\end{abstract}

Keywords: James Watt; Steve Jobs; open innovation; innovation strategy; sustainability; economic growth; innovation entrepreneurship

\section{Introduction}

It was believed that the role of James Watt in making the First Industrial Revolution flourish was similar to that of Steve Jobs who triggered the Fourth Industrial Revolution [1]. Particularly, regarding open innovation-open connection and the combination of technology and market beyond the boundaries of companies-it can be presumed that Watt and Jobs have very similar characteristics as they were both leaders of open innovation and triggered the industrial revolution of an era [2]. Right now, the new mode of digital innovation for prosperity and sustainability—open innovation 2.0 - is proposed. In open innovation 2.0, the notion of a community or ecosystem co-innovating together is central to the new mode of innovation [3]. However, when open innovation is defined as the use of purposive inflows and outflows, or knowledge to accelerate internal innovation and expand the markets for external use of innovation, respectively, open innovation 2.0 is included [4].

At present, creative problem-solving or design-thinking, such as iterative processes or rapid prototyping, are applied to open innovation with the concept of dynamic open innovation $[5,6]$. By the way, the small companies that Watt and Jobs started had good reasons to collaborate with different partners to develop and commercialize new business ideas to discover or recognize new forms of value creation for a particular customer group [7]. However, open innovation not only 
motivates positive dynamics, but also exaggerates the negative dynamics or complexity of open innovation [8,9]. In fact, in turbulent markets such as the First Industrial Revolution and the Fourth Industrial Revolution, companies that have vast open innovation opportunities are more successful than companies with a low extent of open innovation. In addition, technological turbulence, such as the First and Fourth Industrial Revolutions, moderates the effect of supplier integration on innovation success [10].

To innovation and research and development (R\&D) managers including Watt and Jobs, open innovation means the ambition of their companies to open up the innovation process and to cooperate with external partners to accelerate their innovation processes [11]. Watt's patents of a condenser in 1769 and of a rotating piston in 1781 as well as Jobs's NeXTSTEP software sold to Apple, his return to Apple, and the Microsoft's licensing of Windows to the Macintosh operating systems (macOS) show that they used copyright-based open innovation strategies rather than copyleft-based open source innovation [12]. If open innovation in an embedded system is understood by opening embedded systems, it can be said that Jobs used closed innovation strategies in Apple. However, if open innovation in embedded systems is understood without opening embedded systems, it can be said that Jobs took an open innovation approach [13].

With these in mind, this paper poses the following research question: 'What are the differences in the open innovation approaches of James Watt in the First Industrial Revolution and Steve Jobs in the Fourth Industrial Revolution?'

To answer this question, the book review approach is utilized, and the following two books are thus reviewed: (a) Russell, B. James Watt: Making the World Anew; Reaktion Books: London, UK, 2014; (b) Isaacson W. Steve Jobs; Little Brown: London, UK, 2011. In addition, literature review-based thinking experiments are executed, as well as an indirect analysis of interviews with Watt and Jobs from the relevant books, papers, newspapers, and other media sources. This includes Watt's open innovation in the First Industrial Revolution, Job's open innovation in the Fourth Industrial Revolution, and the similarities and differences between the two regarding open innovation. Additionally, relevant papers from the Special Issue of Sustainability entitled "Sustainability of Economic Growth: Combining Technology, Market, and Society" are also reviewed.

\section{James Watt's Open Innovation in the First Industrial Revolution}

\subsection{The First Industrial Revolution}

French philosopher Blaise Pascal (1623-1662) said: "Man is but a reed, the feeblest thing in nature, but he is a thinking reed. The entire universe need not arm itself to crush him" [14] (p. 347). Centuries later, Pascal's dignity of thought remained unchallenged by the First Industrial Revolution even with the invention of the steam engine [15] (p. 91). The First Industrial Revolution depended on Britain's creation of a 'knowledge economy', which became successful for it was able to generate 'useful knowledge' and disseminate it to those who might exploit it commercially [1]. First Industrial Revolution artisans had to develop products that could be sold as well as innovate the techniques they used in their manufacturing processes, devising many new ones but often amplifying and reinventing those that had been well-established and applying them under new circumstances to new materials and products [1].

In the 18th century, it became increasingly likely for Britain to move in pursuit of new opportunities, referring to an increase in the mobility of knowledge. As such, many of the great partnerships of the First Industrial Revolution were comprised of 'an alliance of talent and money'-the partnering of an ingenious mechanic with a gentleman eager to invest his capital [1]. Even though Watt's steam engine is the core of the First Industrial Revolution, automatic machines that were operated simply by supplying power were first invented in the fiber industry. Of course, some automatic machines were manufactured in the iron and printing industries, but the automatic machines before the Industrial Revolution in England were completed in the fiber industry. 
Examples include William Lee's sock-knitting machine, the introduction of a silk reeling machine from Italy to England by John Lombe brothers in 1716, and John Kay's automatic weaver, which led the revolution of the cotton textile industry [16]. In addition, through the dynamic and unbalanced evolution process of the spinning technology, which produces threads from raw cotton, and the cloth weaving technology, the automatic machines of the British fiber industry were developed. Combined with Watt's steam engine, it became the catalyst of the First Industrial Revolution in the UK [17].

The early spinning machine that John Wyatt developed and financed by Lewis Paul in 1732 was registered as a patent in 1738. Based on this technology, James Hargreaves developed the spinning jenny using the principle of the spinning wheel in 1762. In 1768, Richard Arkwright invented the water-frame spinning machine with the application of all the spinning machine technologies and registered the technology as a patent. Unlike previous spinning machine developers who failed their businesses, Arkwright succeeded even though his patent was later canceled. With the development of the spinning mule by Samuel Crompton, production by weaving grew bigger than that by spinning, resulting in a new, unbalanced situation, and thus prompting the need to innovate the spinning technology. In 1785, Edmund Cartwright's invention of the power loom eased the technical imbalance of the fiber industry and led a new technical innovation [16].

As the demand for coal and iron ore increased with the First Industrial Revolution in the horizon, the mining industry developed, and natural power energy (people, animals, water, and wind) used to drain water from mine galleries effectively was changed to that of power from other human-made sources. Thomas Savery invented a suction pump based on the existing theory about steam: vacuum can be created if steam is suddenly cooled down. Thomas Newcomen invented the Newcomen atmospheric engine, which separated a cylinder that created a vacuum and a suction pump. In addition, Humphrey Porter automated the movement of the piston and the openness/closeness of its cover. To create a new steam engine industry, Watt-a theorist-collected information on the innovation of steam engines and met with an entrepreneur who pioneered markets.

The tin cistern represented Watt's leap of imagination: it was his first model of what he called the 'separate condenser', which greatly decreased the engine's use of heat and fuel. The efficiency of his invention compared to the old atmospheric engine was threefold [1]. Watt registered a patent of the condenser developed from an idea that came to mind while walking in the Glasgow campus filled with green space in 1769. Watt's steam engine technology was discovered by multiple entrepreneurs and thus it was introduced into new markets, which resulted in the registration of Watt's second patent, sun-and planet-gear, which changed the straight motion of a piston to that of rotary motion in 1781 [18]. Therefore, the final major improvement in the steam engine was to find a new way of attaching the piston to the beam. Watt developed his 'parallel motion', a parallelogram of metal rods that provided a flexible but resistive connection between the piston rod and the beam [1]. He thus built rotating engines from 1787 until 1800.

McConnel and Kennedy were major British entrepreneurs who owned a large spinning mill with 79,000 spindles in operation and over 1000 employees in the 1810s. In 1793, they already manufactured the latest spinning machine and were the first to have sold a product that utilized Watt's most innovative steam engine in the fiber industry [16]. The first factory that used Watt's steam engine was Albion Mills of Thames Hoban in 1786.

\subsection{James Watt's Open Innovation Characteristics}

Watt was the fourth child of Agnes Muirhead and James Watt Senior but was the first to survive past infancy. He subsequently received much of his education from his mother and tutors-Robert Arrot taught him the basics of Latin while John Marr taught him mathematics [16]. Watt read diverse books, among them Robert Dossie's The Elaboratory Laid Open, or, The Secrets of Modern Chemistry and Pharmacy Revealed (1758); Richard Brookes' The General Practice of Physic (1751); and David Fordyce's Dialogue Concerning Education (1745), which found later additions such as John Croft's Scrapeana (1792), describing itself as "fugitive miscellany; or, a medley of 
choice bons mots, repartees, \&c. to which is added a large collection of Yorkshire anecdotes and sought to expand from ideas into practice." [1] (p. 29). In fact, the technical dexterity of the three generations of the Watt family should not be underestimated as most mechanical inventions came from the machines or equipment improved by sophisticated manual workers [18]. Watt was influenced by his grandfather, a mathematics teacher, and his father, an authorized architect and shipbuilder. As such, he began to manufacture scientific experimental apparatuses during his puberty and moved to Glasgow, the commercial hub of western Scotland at that time. From then on, he manufactured experimental tools at the University of Glasgow, which had been open to students and researchers under the permission of the college [16]. Russell describes Watt from 1736 to 1756 as a sensible, ingenious, and enterprising person.

The University of Glasgow is credited as the first school that contributed greatly to the field of science for establishing a physical laboratory and teaching experiments to students. In addition, it pursued the perfect balance in other fields of study and did not ignore the humanities. For example, the university provided opportunities to Adam Smith, known as the father of modern economics, to teach economics and academically establish the field [18]. Getting invited to Watt's workshop at the University of Glasgow was highly prized among the college students and meeting the customers' needs led Watt into pursuing new ways of making instruments and branching out into retail [1]. Watt worked with scientists such as Joseph Black, famous for his research on calorie wherein water is changed to steam, or what he termed as latent heat, Joe Robinson, and John Anderson.

Black would recall Watt as "a young man possessing [the] most uncommon talents for mechanical knowledge and practice, with an originality, readiness, and conspicuousness of invention, which often surprised and delighted me in our frequent conversation[s] together" [1] (p. 52). Watt's workshop at the university was a 'favorite resort' for Adam Smith during his tenure at the university in that Watt and the older professor established a sufficiently strong rapport for the former's close friends and acquaintances after his retirement in 1800 [1]. Watt recognized several times that he made a great favor to the university's professors who were close to him, saying: "They are all better than me. Even though I did not attend the college, they made me a mechanical engineer" [18] (p. 53). Later, Robinson, who became a professor of the University of Edinburgh, also became a close friend of Watt. As they were of similar age, they talked several times, and Robinson thought Watt was just a mill-hand, but in fact, Watt was a philosopher.

Far from being a solitary craftsman, Watt also assembled a team to help with his work. For example, in February 1758, he looked for "any lad that can file tolerably well" and thereafter, the workforce expanded to a maximum of 14 trained workmen and apprentices [1] (p. 58). In other words, his experience in homeschooling and exchanges with professors at the University of Glasgow and students in his workshop gave him the chance to grow as an engineer who was more familiar with using new products or tools or executing a project with a team rather than doing things alone. With this growth process, Watt's stance toward open innovation is characterized by his willingness to develop new products and solve problems through open connection with other subjects.

\subsection{James Watt's Open Innovation Strategies}

Firstly, James Watt pursued open innovation in his development of a new steam engine. In the winter of 1763-1764, a Newcomen atmospheric engine model was brought to Watt for repair by John Anderson, a professor of the University of Glasgow. Even though the original requirement was only to have it repaired, after more than a year's work, Watt found a solution that would not just fix Anderson's model, but also had the potential to transform the steam engine, based on the theory of Joseph Black, his thinking experiment, and communication with the workshop community. Eventually, Watt returned the model to Anderson with his improvements: for example, he sewed its pump casing in half, and also made more radical measures than Anderson would have countenanced to make it work to his satisfaction [1]. As such, the 'separate condenser' was invented, and the use of which 
minimized the use of heat and fuel in engines. Compared to the old atmospheric engine, it increased the efficiency threefold [1].

Secondly, Watt promoted a strategy that was almost identical with the modern open innovation of diverse open connection: the combination of his steam engine technology and the new market through a partnership with John Roebuck. As capital was essential to perfectly manufacture a steam engine and sell it in the market, Watt decided to collaborate with Roebuck, who managed the Carron Company, an ironworks company, to develop his new steam engine. This was a three-way combination type of open innovation between Roebuck and a new steam-engine technology developer. The three roles were: as a steam engine consumer who used engines for drainage required in mining, as a supplier of related technology such as precise cylinders and pistons essential for the concrete development of a new engine as a president of a steel mill, and as an investment capitalist for the development of a new steam engine, providing full financial support and earning two-thirds of the profits of the patent right [1]. However, in his collaboration with Watt, Roebuck was only successful in his role as a consumer, having failed to supply parts with sufficient quality, such as cylinders, as well as invest enough capital except. As such, the open innovation of developing the first steam engine ended in failure [18].

Thirdly, Watt collaborated with Matthew Boulton who manufactured toys and badges. Watt provided the technology and Boulton offered capital, parts, and markets. Watt succeeded in this attempt to combine steam engines and markets. In 1774, Watt moved into one among five of Soho Foundry's large workshops that Boulton built for metal processing, ceramics, and handiworks. Orders for new steam engines were made from 1775 , but the engines did not sell well in the early days. Boulton derived his business from the manufacture and sales of steam engines such as copper refining and mine management as well as the business of selling copy machines, an invention of Watt. In 1781, the second patent for the 'sun-and-planet gear' of a rotary steam engine was applied, marking a new era in the sales and development of steam engines and the creation of new markets [16].

Rather than building engines from scratch, Watt and Boulton designed, carried out the necessary calculations, produced working drawings, and provided 'engine erectors' from a pool of appropriately skilled men to oversee the day-to-day execution of the construction of each engine, leaving the bulk of the physical work involved in creating parts for each engine was given to others [1]. That is, steam engines were applied to air blowers, rolling mills, and hammers in factories, which significantly improved productivity. John Wilkinson, called the iron master, installed Boulton and Watt steam engines in his factory in Bradley, which gave an opportunity to expand the steam engine market. That led to the explosion of the First Industrial Revolution, which made the creative connection and combination between steam engines and technologies [18]. Of course, the Wilkinson steel mill supplied the best cylinders and accelerated the virtuous circle of open innovation.

Lastly, one of the important strategic selections Watt made during his collaboration-based open innovation processes with Roebuck and Boulton was patent registration. The separate condenser, first registered in 1769, was a touchstone in the business of developing and selling steam engines that, in the case of Watt and Boulton, had an economic profit sharing of 1:2. This led the patent-based distribution of economic profits, and rights thus became an important element in the new collaboration with Boulton for open innovation. Moreover, patents on improvements to the rotary engine, registered for two years from 1781 to 1782, provided foundations for mutual cooperation between Watt Junior and Boulton Junior as well as Watt and Boulton, thus allowing the Boulton and Watt steam engine to explore the diverse, new markets of the Industrial Revolution, connecting it to a new business model, as well as expanding the Industrial Revolution of the 19th century to other European nations including England. 


\section{Steve Jobs' Open Innovation in the Fourth Industrial Revolution}

\subsection{The Fourth Industrial Revolution}

At present, the Fourth Industrial Revolution is building on the third one, the digital revolution that has been occurring since the middle of the last century. It is characterized by a fusion of technologies that is blurring the lines between the physical, digital, and biological spheres [19]. The possibilities of having billions of people connected will be multiplied not just by mobile devices with unprecedented processing power, storage capacity, but also by emerging technology breakthroughs in fields such as artificial intelligence, robotics, the Internet of Things (IoT), autonomous vehicles, 3-D printing, nanotechnology, biotechnology, materials science, energy storage, and quantum computing [20]. The digital fabrication revolution is coming; it draws on the same insights that led to the earlier digitization of communication and computation, but what is now being programmed is the physical world rather than the virtual one [21].

The digital fabrication revolution, for example, will challenge traditional business models. Therefore, profound shifts across all industries are being witnessed, marked by the emergence of new business models, the disruption of incumbents, and the reshaping of production, consumption, transportation, and delivery systems [19]. In addition, as the rise of big data is changing the way people think about the world-in addition to mainly focusing on data use, not data collection-big data in the Big Apple is emerging as new issues in the 21st century [22,23]. Customized robots, including artificial intelligence (A.I.) such as Siri, have the potential to greatly improve the quality of people's lives at home, work, and play. However, we do not know how technological breakthroughs will transform everyday life exactly [24]. In the Fourth Industrial Revolution, including the rise of multi-agent systems in politics, the government should create markets and not just fix them to escape market failure and achieve a smart state $[15,25]$.

However, when we talk about the Fourth Industrial Revolution or the Fourth Revolution, which has an ICT-friendly environment, it should not be confused with others such as the vision of a 'cyborg' humanity—or singularity—-the widespread phenomenon of 'mental outsourcing', or a genetically modified humanity [15]. In the IT era spreading through all industries-the new digital age- the zero marginal cost society is appearing with the sharing economy, and it will reshape the future of the people, nations, and businesses [26]. In the advanced IT-based society, social capital and sharing economy will develop alongside with IoT, 3-D printing, and intelligent infrastructure, among others [27]. In the new digital age, the proliferation of communication technologies or products such as iPhone, iPad, or Apple Watch is being advanced at an unprecedented speed. In the first decade of the 21st century, the number of people connected to the Internet worldwide increased from 350 million to more than 2 billion; within the same period, the number of mobile phone subscribers rose from 750 million to well over a billion [26]. This has significant consequences not only for the industry and business (in other words economic) activities, but also for our cities and societies as the Fourth Industrial Revolution is leading to the formation of the Smart but also Sustainable Cities and Communities of the 21st Century [28-34].

\subsection{Steve Job's Open Innovation Characteristics}

Steve Jobs was put up for adoption by his biological parents and was later adopted by Paul and Clara Jobs. His closest friends believe that the knowledge that he was given up at birth left some scars. Long-time colleague Del Yocan said: "I think his desire for complete control of whatever he makes derives directly from his personality and the fact that he was abandoned at birth" [35] (p. 4). Greg Galhoun, who became close to Jobs right after college, saw another effect: "He wants to control his environment, and he sees the product as an extension of himself" [35] (p. 5). His father, Paul, handed the experiences in complete repair of automobiles, even for invisible sites, to him. Jobs remembered being impressed by his father's focus on craftsmanship: "I thought my dad's sense of design was pretty good because he knew how to build anything" [35] (p. 6). When Steve saw a calf being born, 
which began to walk within minutes, at his father's farm in Wisconsin, he recalled saying: "A human baby couldn't do that. I found it remarkable, even though no one else did." Putting it in hardware and software terms, he commented: "It was as if something in the animal's body and in its brain had been engineered to work together instantly rather than being learned" [35] (p. 16).

At 11 years old, the Jobs family moved to the flatlands of Los Alto and found themselves smack in the middle of what may have been the largest assemblage of science works ever gathered in one place since the Manhattan Project [36]. As there were many technicians who could teach him technical knowledge, Jobs went around garages after school. Here, he faced the most diverse technical environment. It was also around this time that he met Bill Fernandez at his new school, Cupertino Junior High School, and Steve Wozniak, well-known as a computer genius in this town. Fernandez also introduced him to Silicon Valley. It can thus be seen that his childhood town was the most open space in the world that awoke his awareness of new technology and a new era. While Wozniak knew technologies, Jobs possessed intestinal fortitude: he always achieved a goal once he set it. As a young man, he pursued spiritual life with psychedelic drugs and religious exploration. This spiritual sensibility contributed greatly to the unusual breadth of his intellectual peripheral vision, which eventually led him to see possibilities that ranged from great new products to radically reinvented business models, which escaped most people [37]. Just as Silicon Valley was the environment that birthed and nurtured Steve's technological optimism, the 1960s was also the decade that fueled the inquisitive teen's natural impulse to search for deeper truths. The messages of the time were clear: "question everything, especially authority; experiment; hit the road; be fearless; and work to create a better world" [37] (p. 30).

After going to high school, Jobs joined an electronics club and learned about the latest trends in the global computer industry. In addition, he generally understood the electronic components market at an early age while working at Haltech, an electronic components store [36]. With Jobs' help, Wozniak developed the first digital 'blue box' - a machine that could mimic the tones used by telephone company switches to connect specific phones anywhere in the world. Wozniak polished his circuit design, while Steve pulled together the necessary materials and priced the finished boxes [29]. It was then that they reached an important milestone, one that would establish a pattern in their partnerships: Jobs came up with the idea that the blue box could be more than a mere hobby. They could actually build and sell them. Jobs said that-foreshadowing the roles he would play when they founded Apple- "I got together the rest of the components, like the casing and power supply and keypads, and figured out how we could price it" [35] (p. 29).

Reed College, which Steve Jobs entered, only had 1000 students-half the number at Homestead High. The college was also known for its free-spirited, hippie lifestyle, which combined somewhat uneasily with its rigorous academic standards and core curriculum [35]. After dropping out after just one semester, he took second-semester auditing classes, including one calligraphy course that he would later cite as the inspiration for the Macintosh's ability to produce a diverse panoply of typographical fonts. Around this time, he also delved more deeply into Asian philosophy and mysticism, and dropped acid with greater frequency, almost as a spiritual sacrament [37]. Many times, Jobs said that his experiences at Reed College gave him an important opportunity to adopt an open attitude to access technologies and markets. In addition, his engagement with Eastern spirituality, particularly Zen Buddhism at the college, was not just some passing fancy or youthful dabbling; he embraced it with his typical intensity, and it became deeply ingrained in his personality, reflected in his whole approach of stark, minimalist aesthetics, intense focus, and intuitive understanding and consciousness rather than abstract thinking and intellectual, logical analysis [35]. A Zen Buddhism-based recognition structure thus became the base of the open connection and combination between technology and market, going beyond logical access, whenever Jobs pursued a new product and a new innovation. In other words, it became the base of open innovation and new business model development. 


\subsection{Steve Jobs' Open Innovation Strategies}

It is very impressive that Jobs threw questions after making Apple 1 with Wozniak and establishing a company. Jobs peppered Wozniak with questions: 'Could the computer ever be networked? Was it possible to add a disk for memory storage?' He also began helping Wozniak get components. Particularly important were the dynamic random-access memory chips: Jobs already thought about a computer that would have the memory capacity to connect between individual computers before developing the first computer. In other words, in the first meeting, Jobs' vision of the personal computer (PC) market and Wozniak's new class of board-based computer technology were thus combined [35]. It was said that it was decisive when Jobs persuaded Wozniak into finding a company: "Even if we lose our money, we'll have a company" [35] (p. 61).

Their roles were clearly identified when the two founders presented their first computer to Homebrew Computer Club, a computer club in the Silicon Valley. First, Wozniak emphasized: a human-typeable [ergonomic] keyboard instead of an ineffective, cryptic front panel with a bunch of lights and switches. However, when Job's turn to speak came, he said, "Apple has all the essential components built in" and proceeded to ask how much the people intended to pay for this new computer [36] (p. 34). In other words, Wozniak paid attention to Apple's technology, and Jobs focused on marketing Apple. The two created a new business model that did not yet exist at the time: the PC market. Jobs' excellence was imminent: after just 30 days, Apple was on the verge of being profitable [36]. Years later, Wozniak explained: "We felt it was going to affect every home in the country"; they believed that they were going to change people's lives by giving them technology that they did not know they needed and would be different from anything they knew [37] (p. 37).

Steve Jobs, who was in charge of developing Apple's next-generation computer the Macintosh, simply established the concept of a PC that could be easily and conveniently used. He and Apple hired two engineers from Hewlett-Packard to develop a completely new computer. Jobs directly checked Palo Alto Research Center Incorporated's (PARC's) graphical user interface (GUI) system and confessed: "I could see what the future of computing was destined to be." A week later, he hired Larry Tesler, a senior researcher of PARC, and declared that Apple would make a computer implementing the GUI system within six months [37] (p. 71). Jobs said: "Picasso had a saying-'Good artists copy, great artists steal'—and we have always been shameless about stealing great ideas" [28] (p. 98). This expression described the willingness of open innovation, as declared by Jobs, in the best and most unacademic way. In addition, the vision Jobs' showed to the Macintosh development team was "Let's be pirates" [36] (p. 58). It suggested an implicative vision of finding the technologies and ideas that existed in the world, as well as new markets, and publicly connecting them for new innovation.

Another open innovation case of Jobs is the innovation process of Pixar. Jobs recalled the moment he visited Lucasfilm's computer division: "I wanted to buy it because I was really into computer graphics. I realized they were way ahead of others in combining art and technology, which is what I've always been interested in" [35] (p. 239). While NeXT Computer, founded after being expelled from Apple, did not generate revenue well, Jobs newly combined design technology with a computer with the belief that it would lead to the creation of a new computer or market. What Jobs did not know in 1986 was that Pixar would give him something much more valuable than technology to squeeze into NeXT [37]. Finally, the combination between excellent design and computer technology led to successful open innovation: the creation of a new market, a new class of computer graphic animation. Through Apple 1, Jobs experienced that open innovation-creative connection and the combination of technology and market—could lead to the creation of a completely unexpected market or product or even one that was yet to exist.

Jobs, who returned to Apple and gained huge success with the iPod, expressed his concern to the board of directors: 'The device that can eat our lunch is the cell phone'. He went on to explain that the digital camera market was presently being decimated as phones were now equipped with cameras, and that the same could happen to the iPod [37]. However, the open innovation strategy Jobs promoted under the situation was very surprising. He called Ed Zander, the new CEO of Motorola 
who was in charge of the production of the company's popular RZAZ that dominated the global cell phone market at the time and suggested a collaboration for a cell phone and digital camera device that would have a built-in iPod. The first trial for an Apple smartphone failed, but it did leave several lessons. After that, Jobs got a hint from Bill Gates and started the development of a multi-touch-based smartphone without any keyboard. For this, Apple took over companies that owned touchscreen technology like FingerWorks to acquire new technologies within a short period in a more mature manner. This is the moment that it can be said that Jobs became a master of open innovation strategies that can actively secure outside technologies and new markets in a more sophisticated manner by anticipating the development of iPhone. In fact, in the early days of Apple, Jobs would go outside the company to get inspiration for creative aspects like product design and advertising. He blindly followed the corrupt "Not Invented Here" philosophy; he would totally break out of that prison when he developed iPhone [36] (p. 279).

\section{Similarities and Differences between James Watt's and Steve Jobs' Open Innovation}

\subsection{Open Innovation Approach Similarities}

Firstly, both James Watt and Steve Jobs grew up in situations that enabled them to experience diverse things such as new technologies, markets, and cultures within a space that invited open-mindedness. Watt acquired various knowledge and information-mathematics, science, culture, and language - through the comprehensive homeschooling he received from his parents. In addition, he also had the opportunity to operate his own workshop that manufactured and sold teaching aids at the University of Glasgow, as well as meet the world's top physicists, chemists, economists, and philosophers. In addition, he was also able to make exchanges with entrepreneurs near the university during a time when the Industrial Revolution was actively growing in Scotland and London, allowing him to have direct knowledge of the trends and changes in the global market.

On the other hand, Jobs grew close with engineers in the science and technology fields that started to exponentially grow-in IT in particular-around his home near Silicon Valley. In addition, through Homebrew Computer Club-a club that was open to all youngsters interested in computers, regardless of academic background and job-he met Wozniak, early consumers of Apple 1, and people from diverse background, which was necessary for the growth of Apple. Furthermore, Reed College was a stronghold of the most open hippie culture in the western world, and his experiences there gave him the chance to have an open mind to diverse culture, philosophy, and arts. During his college years, his preference for Bob Dylan songs and the like helped him forge an effective alliance with Wozniak. In addition, his openness to culture became the base of open innovation access. In the case of Pixar or during the process of developing iPod and iPhone, his openness to culture became an important foundation of access to open innovation.

Secondly, both have an open-minded attitude to the humanities, society, and arts as well as various science and technology fields. It can be presumed that some similar actions during their growth may have affected their open innovation characteristics. Watt underwent homeschooling instead of regular education and did not attend college. Instead, he manufactured and sold teaching aids in a university and solved engineering problems that Glasgow students and professors and companies faced through the workshop he had organized. Through the experiences, he developed his engineering capacity, and it could be deduced that the process of accumulating the experiences, which were not stereotyped, allowed him more flexibility in handling engineering problems and boldly accessing them differently.

Moreover, the University of Glasgow was the top science and technology university in Scotland but also had respect for the humanities and social science fields. Adam Smith, the renowned father of modern economics, was tenured, and this university also made significant contributions to the Industrial Revolution in the history and philosophy sectors. In this situation, Watt had in-depth philosophical introspection and literary sensitivity. Moreover, he made a steam engine and developed the capacity to flexibly connect with others during various moments for combining the engine and the 
Industrial Revolution. Similarly, Jobs did not have enough formal school education. He simply took a class for a semester and audited a class for another at a university. However, under Reed College's open atmosphere at the time, he had the chance to accumulate diverse knowledge and experiences in various fields such as philosophy, humanities, and the arts, including music. In addition, with his accumulated experiences in Silicon Valley where he grew up, he also had the chance to work with Atari, a game company, and Haltech, where he sold electronic components; Jobs had diverse experiences with an open mind within the computer industry, which was experiencing exponential growth at the time.

Thirdly, Watt and Steve Jobs confidently used the open innovation strategy of collaborating with other technology or market experts or companies, instead of handling everything independently when exploring a new technology or market during product innovation and corporate growth. In fact, it needs to be pointed out that even though open innovation became a major paradigm in the late 20th or in the 21st century, during the time of Watt or when Jobs founded Apple, closed innovation based on the 'Not Invented Here' syndrome was dominant. Watt collaborated with the world's top physicists in the latent heat research field at the University of Glasgow while developing his steam engine, a university professor who requested the repair of the existing steam engine, and others during the early stages of his development of the steam engine. In addition, Watt also collaborated with Roebuck, who operated a steel mill, when combining his steam engine with the market, and also had the chance to develop a new engine and apply the technology to mining. Furthermore, the collaboration with Boulton, who had markets in European countries and operated diverse manufacturing firms, became a driving force that combined the steam engine of Boulton and Watt and diverse industries, which led the explosion of the Industrial Revolution in the textile, iron, and manufacturing tool industries. Watt's diverse open innovation became a myth of the First Industrial Revolution by supplying engines to John Wilkinson's steel mill and receiving perfect cylinders and pistons from the mill in return. For Jobs, his collaboration with the genius engineer Wozniak for the development of Apple 1 and 2 and establishment of the company, Apple, became his foundation for success in the computer sector. Of course, their collaboration became a platform of success: the development of Wozniak's blue box and in its subsequent commercialization by Jobs, including the mutual collaboration of open innovation in the previous stage [38].

In addition, Jobs explored a new graphic-based PC technology rather than coding, which he subsequently suggested for the development and sales of Macintosh and its market, through an open innovation strategy in an unsophisticated manner-source technology transfer from PARC. Furthermore, Jobs collaborated with Tesler for the creation of the computer-based animation sector of Pixar and Disney, industry giants for technology development and market creation, in a more mature way through open innovation strategies. Jobs also collaborated with Motorola for the development of the iPhone and the creation of a new market of smartphones, used Bill Gates' touchscreen idea, and applied more diverse open innovation strategies for mergers and acquisitions (M\&A) with unknown companies like touchscreen firms to source technologies for the manufacture of smartphones. This is very similar to the case of Phil Knight, the founder of NIKE. When he created and expanded its market, he collaborated with Bill Bowerman, a sports shoe technical developer, American track coach, and the world's top sports shoe research developer. In addition, Onitsuka, a Japanese shoe company, allowed open innovation collaboration for market creation and introduced NIKE [39]. Furthermore, this is also very similar to the collaboration between Sergey Brin and Larry Page, which greatly developed new search engine markets that did not yet exist, using the new technology with the Page Rank algorithm as the basis, and the open innovation of Google with numerous companies [40,41].

\subsection{Open Innovation Approach Differences}

First of all, Watt's open innovation was based on patents, but that of Jobs was on markets-this was a clear difference. The separate condenser, first registered by Watt in 1769, was the standard of the 
collaboration with Roebuck and diverse open innovation. It signified that the profits generated from the patent was divided into 1:2 between Watt and Roebuck, respectively, and that the patent-based steam engine was developed through the huge investment made by Roebuck's Carron Company. They were introduced to each other by Joseph Black, a professor of the University of Glasgow and the world's top researcher in the latent heat sector and continued to collaborate with each other. They practically made collaborations for the investment of Roebuck and the manufacture of cylinders in his steel mill. During the process, Roebuck went bankrupt due to the failure of the coal mining process, first created in the market to use this steam engine. Thus, their open innovation ended.

Next, Watt successfully collaborated with Boulton and applied open innovation strategies of creating diverse technologies and markets based on the rotary engine patent registered in 1782, which was also the first patent. Thus, the Boulton and Watt steam engine- - the symbol of the First Industrial Revolution-dominated the market. Their collaboration extended to their respective children upon the turnover. On the other hand, Jobs created a PC market with the development of Apple 1, made possible with Wozniak's technology, rather than developing a patent. Through the open innovation during the development of Macintosh, he did not develop a new patent or collaborate with others based on a patent; instead, he created a new GUI-based PC market. He created a new computer-based animation market, which was not based on a patent, while collaborating with Disney. In his development of the iPhone, Jobs pursued open innovation strategies. Rather than registering a patent, he focused on securing talents with source technology. Instead of developing a new technology, he combined diverse technologies that already existed and created a new smartphone market that was of practical size and quality.

Secondly, Watt promoted technology-based open innovation strategies, but Jobs did market-based open innovation ones. Watt established his position as an excellent engineer, well-known in London and Glasgow, and created new technologies and markets through situation-based, diverse open innovation strategies. Of course, Watt, an excellent engineer, did not pursue closed technology development; he collaborated with many engineers with potential for technology development, because he did not receive formal school education. In addition, through open innovation, he merged with a company in a specific sector to create a market. However, even though Jobs was the originator of a professional science design - a general engineer in the modern sense-he concentrated on the role of creating a market and pursued diverse open innovation strategies to acquire technologies [34]. In the collaboration with Wozniak, Jobs paid attention to the creation of the PC market. For example, Jobs defined PC market when developing Apple 2, suggested a telephone directory with a size suitable for laboratory PCs, and made a request for matching the telephone book with a PC to Wozniak and the development team.

Jobs was in charge of the overall development of the Macintosh, but his role was to suggest the mouse and graphics-based PC market with high specification and to lead the developers. At the time, he revealed his visions: 'Become a pirate', 'Journey is reward', 'Think different', and so on-to lead engineers and thus allow them to develop technologies suitable for the market that Jobs proposed. In the case of Pixar, he suggested a new computer market with excellent graphics, and engineers made software that meet his requirements. Thus, Pixar partially resolved its difficulties in financing. The possibility of the market, which was recognized as a computer-based animation market before Jobs took over the company, was shown to Jobs. Even though he knew of a new concept in the computer-based animation market, he collaborated with Disney through open innovation and exponentially extended open innovation. During the development of the iPhone, Jobs suggested a new concept and perfected the smartphone market by utilizing the existing computer functions such as easy-to-use and touch-based functions, iPod for playing music, and the Internet. In addition, the technologies necessary for the creation of this market were implemented through the technologies and manpower introduced through comprehensive, sophisticated, and diverse open innovation strategies like M\&A, R\&D investments, and partnerships. 
Thirdly, Watt preferred workshop, lecture, and letter-writing to communicate with others, but Jobs did insanely great presentations in front of an audience [42]. Watt enjoyed opening his small store of teaching aids at the University of Glasgow and suggesting alternatives for academic and practical problems or requirements of professors through seminars or lectures with students, professors, and entrepreneurs. At Boulton's Soho Foundry, he also enjoyed meeting or discussing with other engineers, people in related companies or sectors, and students for the engines he developed and continuously improved, thus accumulating new ideas through the process. In addition, Watt continued to communicate with people through letters for additional discussion needed for this process during his lifetime [18]. However, Jobs was best as a presenter. As the last stage of innovation for a new product that would create and lead a new market, such as the Macintosh, iPod, iPhone, and iPad, he explained it to the people so that they would fully understand it. It is presumed that he was fully aware in the last stage of innovation to create a new market, it was important to emotionally and rationally give people-including the press and related experts-information on the new market of a product. 'We are here to put a dent in the universe', 'Today, Apple reinvents the phone with iPhone', and '1000 songs in your pocket', which were part of his distinct presentation style at the last stage of market creation [42].

\section{Sustainability of Economic Growth: Combining Technology, Market, and Society}

This special issue entitled 'Sustainability of Economic Growth: Combining Technology, Market, and Society' has 19 papers related to James Watt's and Steve Jobs' above-presented open innovation approaches and strategies.

Nine papers from the special issue relate to the Jobs' open innovation perspective, and highlight the following:

Firstly, the effect of distance between technology and market to open innovation was analyzed in relation to the triple-helix open innovation $[43,44]$. Secondly, the moderating role of social media for entrepreneurial opportunity was reviewed in relation to the Schumpeterian dynamics of open innovation $[9,45]$. Thirdly, the efficiency of retail chain stores was analyzed in relation to the business model prism approach [46,47]. Fourthly, fashion trendsetting, creative traits and behaviors, and pro-environmental behaviors of Korean and American college students in relation to the open innovation education model were compared [48,49]. Fifthly, the relationship between the efficiency, service quality, and customer satisfaction for state-owned commercial banks in China was analyzed in relation to the arts catalyst of creative organizations for the Fourth Industrial Revolution [50,51]. Sixthly, taking the normative dimensions in the innovation systems for transformations toward sustainability was analyzed in relation to the economics of industrial innovation [52]. Seventhly, the consumer acceptance of the home energy management system was analyzed with relation to micro open innovation dynamics [2]. Eighthly, participatory public service design by the Government 3.0 design group was studied in relation with the problem, thinking about what kind of innovation was needed to secure the future $[53,54]$. Ninthly, the tradeoff relationship between sustainability orientation and entrepreneurship orientation was analyzed in relation to the business school crisis [55,56].

Ten papers from the special issue relate to the Watt's open innovation perspective, and highlight the following:

Firstly, factors for dismantling the inverted U-Curve of open innovation were analyzed in relation to the open innovation network perspective [57-59]. Secondly, effective incentive design to reduce food waste was analyzed through a natural experiment of policy change from a community-based charge to a radio-frequency identification-based (RFID) weight charge, in relation to the RFID open innovation perspective $[60,61]$. Thirdly, the effect of global warming, which leads to phonological responses in the process of urbanization in the south, was analyzed in relation to the Schumpeterian dynamics of open innovation, including social innovation $[9,62]$. Fourthly, innovation production scheduling for customer satisfaction-based measurement was analyzed in relation to the open-innovation smart city approach $[63,64]$. Fifthly, the key driving forces for geo-economic relationships between China 
and the Association of Southeast Asian Nations (ASEAN) countries were analyzed in relation to the virtues of variety on regional innovation system [65]. Sixthly, the innovation ecosystem of compressed natural gas (CNG) vehicles was analyzed through a case study of its cultivation and characteristics in Sichuan, China in relation to the micro-dynamics of open innovation $[2,66]$. Seventhly, a long-term collaboration network based on the clinicaltrials.gov database in the Pharmaceutical industry was analyzed in relation to the social inclusive innovation perspective $[67,68]$. Eighthly, the collaborative development within the Beijing-Tianjin-Hebei region in China were evaluated in terms of performance and elucidated the mechanisms in relation to the micro open innovation dynamics [2,69]. Ninthly, simulation of weak nanotechnology innovation signals was done within the complex system condition, in relation to the complex, adaptive system approach [70,71]. Tenthly, evaluating the collaborative ecosystem for an innovation-driven economy was executed through system analysis and a case study of science parks in relation to the open innovation cluster [72-76].

Lastly, the editors believe the special issue contributes to the academic knowledge and professional practice in interdisciplinary fields relating to open innovation and will generate insights for achieving sustainability of economic growth through combining technology, market, and society via successful and innovative strategies.

Author Contributions: J.J.Y. led the guest editing of the special issue and drafted this Editorial piece. K.J. and T.Y. supported the special issue as co-guest editors and contributed to the finalization of the Editorial piece.

Funding: This work was supported by the DGIST R\&D Program of the Ministry of Science, Technology, and ICT (\#18-IT-01).

Acknowledgments: Editors are grateful to the DGIST R\&D Program (18-IT-01) of the Ministry of Science, Technology, and ICT for the funding provided, and special issue paper contributors for their quality research outcomes.

Conflicts of Interest: The authors declare no conflict of interest.

\section{References}

1. Russell, B. James Watt: Making the World Anew; Reaktion Books: London, UK, 2014.

2. Yun, J.J.; Won, D.; Park, K. Dynamics from open innovation to evolutionary change. J. Open Innov. Technol. Mark. Complex. 2016, 2, 7. [CrossRef]

3. Martin Curley, B.S. Open Innovation 2.0: The New Mode of Digital Innovation for Prosperity and Sustainability; Springer: Basel, Switzerland, 2017.

4. Chesbrough, H. New puzzles and new findings. In Open Innovation: Researching a New Paradigm; Henry Chesbrough, H., Vanhaverbeke, W., West, J., Eds.; Oxford University Press: New York, NY, USA, 2006.

5. Fisher, W. Applying the creative problem solving process to open innovation. In Open Innovation: Academic and Practical Perspectives on the Journey from Idea to Market; Markman, A.B., Ed.; Oxford University Press: New York, NY, USA, 2016.

6. Yun, J.J. Business Model Design Compass: Open Innovation Funnel to Schumpeterian New Combination Business Model Developing Circle; Springer: Singapore, 2017.

7. Vanhaverbeke, W. Managing Open Innovation in SMEs; Cambridge University Press: Cambridge, UK, 2017.

8. Hopkins, M.M.; Tidd, J.; Nightingale, P. Positive and negative dynamics of open innovation. In Open Innovation Research, Management and Practice; Imperial College Press: London, UK, 2014; pp. 417-443.

9. Yun, J.J. How do we conquer the growth limits of capitalism? Schumpeterian dynamics of open innovation. J. Open Innov. Technol. Mark. Complex. 2015, 1, 17. [CrossRef]

10. Schweitzer, F.; Gaubinger, K.; Gassmann, O. The role of open innovation in dynamic environments. In Open Innovation Research, Management and Practice; World Scientific Publishing: Singapore, 2013.

11. Nedon, V. Open Innovation in RED Departments: An Analysis of Employees' Intention to Exchange Knowledge in OI-Projects; Gabler Verlag: Wiesbaden, Germany, 2015.

12. Ehls, D. Joining Decisions in Open Collaborative Innovation Communities: A Discrete Choice Study; Springer Gabler: Wiesbaden, Germany, 2013.

13. Soeldner, C.-C. Open Innovation in Embedded Systems; Gabler Verlag: Wiesbaden, Germany, 2017.

14. Pascal, B. Pensees and Other Writings; Oxford University Press: New York, NY, USA, 1999. 
15. Floridi, L. The Fourth Revolution: How the Infosphere is Reshaping Human Reality; Oxford University Press: New York, NY, USA, 2014.

16. Yonekura, S. Keiei Kakumei No Kouzo; Iwanami Shoten: Tokyo, Japan, 1999.

17. Rosenberg, N.; Frischtak, C.R. Technological innovation and long waves. Camb. J. Econ. 1984, 8, 7-24.

18. Carnegie, A. James Watt; Cosimo Inc.: New York, NY, USA, 2005.

19. Schwab, K. The Fourth Industrial Revolution; Crown Business: New York, NY, USA, 2017.

20. Schwab, K. The fourth industrial revolution: What it means and how to respond? In The Fourth Industrial Revolution: A Davos Reader; Rose, G., Ed.; Council on Foreign Relations: New York, NY, USA, 2016; pp. 234-250.

21. Gershenfeld, N. How to make almost anything: The digital fabrication revolution. In The Fourth Industrial Revolution: A Davos Reader; Rose, G., Ed.; Council on Foreign Relations: New York, NY, USA, 2016; pp. 12-20.

22. Cukier, K.; Mayer-Schoenberger, V. The rise of big data: How it's changing the way we think about the world. Foreign Aff. 2013, 92, 28-40.

23. Mundie, C. Privacy pragmatism: Focus on data use, not data collection. Foreign Aff. 2014, 93, $28-38$.

24. Rus, D. The robots are coming: How technological breakthroughs will transform everyday life. Foreign Aff. 2015, 94, 2-7.

25. Mazzucato, M. The innovative state: Governments should make markets, not just fix them. Foreign Aff. 2015, 94, 61-68.

26. Eric Schmidt, J.C. The New Digital Age: Reshaping the Future of People, Nations and Business; Knopf: New York, NY, USA, 2016.

27. Rifkin, J. The Zero Marginal Cost Society; St. Martin's Griffin: New York, NY, USA, 2014.

28. Yigitcanlar, T. Smart cities: An effective urban development and management model? Aust. Plan. 2015, 52, 27-34. [CrossRef]

29. Yigitcanlar, T.; Lee, S. Korean ubiquitous-eco-city: A smart-sustainable urban form or a branding hoax? Technol. For. Soc. Chang. 2014, 89, 100-114. [CrossRef]

30. Yigitcanlar, T.; Kamruzzaman, M.; Buys, L.; Ioppolo, G.; Sabatini-Marques, J.; Costa, E.; Yun, J. Understanding 'smart cities': Intertwining development drivers with desired outcomes in a multidimensional framework. Cities 2018, in press. [CrossRef]

31. Yigitcanlar, T.; Kamruzzaman, M. Does smart city policy lead to sustainability of cities? Land Use Policy 2018, 73, 49-58. [CrossRef]

32. Yigitcanlar, T. Technology and the City: Systems, Applications and Implications; Routledge: New York, NY, USA, 2016.

33. Dizdaroglu, D.; Yigitcanlar, T.; Dawes, L. A micro-level indexing model for assessing urban ecosystem sustainability. Smart Sustain. Built Environ. 2012, 1, 291-315. [CrossRef]

34. Yigitcanlar, T.; Dizdaroglu, D. Ecological approaches in planning for sustainable cities: A review of the literature. Glob. J. Environ. Sci. Manag. 2015, 1, 159-188.

35. Isaacson, W. Steve Jobs; JC Lattès: Paris, France, 2011.

36. Jeffrey, Y.S.; Simon, W.L. iCon Steve Jobs: The Greatest Second Act in the History of Business; Wiley \& Sons: Hoboken, NJ, USA, 2006.

37. Schlender, B.; Tetzeli, R. Becoming Steve Jobs: The Evolution of a Reckless Upstart into a Visionary Leader; Crown Business: New York, NY, USA, 2015.

38. Wozniak, S.; Smith, G. Iwoz: Computer Geek to Cult Icon: How I Invented the Personal Computer, Co-Founded Apple, and Had Fun Doing It; W. W. Norton \& Company: New York, NY, USA, 2007.

39. Knight, P. Shoe Dog: Die Offizielle Biografie des Nike-Gründers; FinanzBuch Verlag: München, Germany, 2016.

40. Schmidt, E.; Rosenberg, J. How Google Works; Grand Central Publishing: New York, NY, USA, 2014.

41. Baskerville, R. What design science is not. Eur. J. Inf. Syst. 2008, 17, 441-443. [CrossRef]

42. Gallo, C. The Presentation Secrets of Steve Jobs: How to Be Insanely Great in Front of Any Audience; McGraw-Hill: New York, NY, USA, 2009.

43. Leydesdorff, L.; Ivanova, I. "Open innovation" and "triple helix" models of innovation: Can synergy in innovation systems be measured? J. Open Innov. Technol. Mark. Complex. 2016, 2, 11. [CrossRef]

44. Yun, J.J.; Jeong, E.; Lee, C.; Park, J.; Zhao, X. Effect of distance on open innovation: Differences among institutions according to patent citation and reference. Sustainability 2017, 9, 1478. [CrossRef] 
45. Park, J.Y.; Sung, C.S.; Im, I. Does social media use influence entrepreneurial opportunity? A review of its moderating role. Sustainability 2017, 9, 1593. [CrossRef]

46. Ko, K.; Chang, M.; Bae, E.S.; Kim, D. Efficiency analysis of retail chain stores in Korea. Sustainability 2017, 9 , 1629. [CrossRef]

47. Schiuma, G.; Lerro, A. The business model prism: Managing and innovating business models of arts and cultural organisations. J. Open Innov. Technol. Mark. Complex. 2017, 3, 13. [CrossRef]

48. Ah Kim, S.; Yun Ryoo, H.; Joo Ahn, H. Student customized creative education model based on open innovation. J. Open Innov. Technol. Mark. Complex. 2017, 3, 6. [CrossRef]

49. Workman, J.; Lee, S.H.; Jung, K. Fashion trendsetting, creative traits and behaviors, and pro-environmental behaviors: Comparing Korean and U.S. College students. Sustainability 2017, 9, 1979. [CrossRef]

50. Chang, M.; Jang, H.B.; Li, Y.M.; Kim, D. The relationship between the efficiency, service quality and customer satisfaction for state-owned commercial banks in China. Sustainability 2017, 9, 2163. [CrossRef]

51. Schiuma, G. Arts catalyst of creative organisations for the fourth industrial revolution. J. Open Innov. Technol. Mark. Complex. 2017, 3, 20. [CrossRef]

52. Schlaile, M.P.; Urmetzer, S.; Blok, V.; Andersen, A.D.; Timmermans, J.; Mueller, M.; Fagerberg, J.; Pyka, A. Innovation systems for transformations towards sustainability? Taking the normative dimension seriously. Sustainability 2017, 9, 2253. [CrossRef]

53. Baek, S.; Kim, S. Participatory public service design by Gov. 3.0 design group. Sustainability 2018, $10,245$. [CrossRef]

54. Witt, U. What kind of innovations do we need to secure our future? J. Open Innov. Technol. Mark. Complex. 2016, 2, 17. [CrossRef]

55. Phillips, F.; Hsieh, C.H.; Ingene, C.; Golden, L. Business schools in crisis. J. Open Innov. Technol. Mark. Complex. 2016, 2, 10. [CrossRef]

56. Sung, C.S.; Park, J.Y. Sustainability orientation and entrepreneurship orientation: Is there a tradeoff relationship between them? Sustainability 2018, 10, 379. [CrossRef]

57. Yun, J.J.; Jeong, E.; Park, J. Network analysis of open innovation. Sustainability 2016, 8, 729. [CrossRef]

58. Yun, J.J.; Won, D.; Jeong, E.; Park, K.; Lee, D.; Yigitcanlar, T. Dismantling of the inverted U-curve of open innovation. Sustainability 2017, 9, 1423. [CrossRef]

59. Yun, J.; Lee, D.; Ahn, H.; Park, K.; Lee, S.; Yigitcanlar, T. Not deep learning but autonomous learning of open innovation for sustainable artificial intelligence. Sustainability 2016, 8, 797. [CrossRef]

60. Jung, K.; Lee, S. A systematic review of rfid applications and diffusion: Key areas and public policy issues. J. Open Innov. Technol. Mark. Complex. 2015, 1, 9. [CrossRef]

61. Lee, S.; Jung, K. Exploring effective incentive design to reduce food waste: A natural experiment of policy change from community based charge to RFID based weight charge. Sustainability 2017, 9, 2046. [CrossRef]

62. Lee, S.-D. Global warming leading to phenological responses in the process of urbanization, South Korea. Sustainability 2017, 9, 2203. [CrossRef]

63. Lara, A.P.; Da Costa, E.M.; Furlani, T.Z.; Yigitcanlar, T. Smartness that matters: Towards a comprehensive and human-centred characterisation of smart cities. J. Open Innov. Technol. Mark. Complex. 2016, 2, 8. [CrossRef]

64. Shim, S.O.; Park, K.; Choi, S. Innovative production scheduling with customer satisfaction based measurement for the sustainability of manufacturing firms. Sustainability 2017, 9, 2249. [CrossRef]

65. Cooke, P. The virtues of variety in regional innovation systems and entrepreneurial ecosystems. J. Open Innov. Technol. Mark. Complex. 2016, 2, 13. [CrossRef]

66. Ding, L.; Wu, J. Innovation ecosystem of cng vehicles: A case study of its cultivation and characteristics in Sichuan, China. Sustainability 2018, 10, 39. [CrossRef]

67. Gupta, A.; Dey, A.; Singh, G. Connecting corporations and communities: Towards a theory of social inclusive open innovation. J. Open Innov. Technol. Mark. Complex. 2017, 3, 17. [CrossRef]

68. Yang, H.; Lee, H.J. Long-term collaboration network based on ClinicalTrials.Gov database in the pharmaceutical industry. Sustainability 2018, 10, 322. [CrossRef]

69. Fang, C.; Luo, K.; Kong, Y.; Lin, H.; Ren, Y. Evaluating performance and elucidating the mechanisms of collaborative development within the Beijing-Tianjin-Hebei region, China. Sustainability 2018, 10, 471. [CrossRef]

70. Won, D.; Yoo, S.; Yoo, H.; Lim, J. Complex adaptive systems approach to Sewol ferry disaster in KOREA. J. Open Innov. Technol. Mark. Complex. 2015, 1, 22. [CrossRef] 
71. Yoo, S.H.; Won, D. Simulation of weak signals of nanotechnology innovation in complex system. Sustainability 2018, 10, 486.

72. Rothgang, M.; Cantner, U.; Dehio, J.; Engel, D.; Fertig, M.; Graf, H.; Hinzmann, S.; Linshalm, E.; Ploder, M.; Scholz, A.M.; et al. Cluster policy: Insights from the german leading edge cluster competition. J. Open Innov. Technol. Mark. Complex. 2017, 3, 18. [CrossRef]

73. Yan, M.R.; Chien, K.M.; Hong, L.Y.; Yang, T.N. Evaluating the collaborative ecosystem for an innovation-driven economy: A systems analysis and case study of science parks. Sustainability 2018, 10, 887. [CrossRef]

74. Rose, G. (Ed.) The Fourth Industrial Revolution: A Davos Reader; Foreign Affairs Special Collection: New York, NY, USA, 2016.

75. Yigitcanlar, T.; Bulu, M. Dubaization of Istanbul: Insights from the knowledge-based urban development journey of an emerging local economy. Environ. Plan. A 2015, 47, 89-107. [CrossRef]

76. Baum, S.; O'Connor, K.; Yigitcanlar, T. The implications of creative industries for regional outcomes. Int. J. Foresight Innov. Policy 2008, 5, 44-64. [CrossRef]

(C) 2018 by the authors. Licensee MDPI, Basel, Switzerland. This article is an open access article distributed under the terms and conditions of the Creative Commons Attribution (CC BY) license (http:/ / creativecommons.org/licenses/by/4.0/). 